International Journal of Social Sciences and Humanities
Available online at http://sciencescholar.us/journal/index.php/ijssh
Vol. 3 No. 2, July 2019, pages: 47 61
e-ISSN: 2550-7001, p-ISSN: 2550-701X
https://doi.org/10.29332/ijssh.v3n2.292

\title{
An Exploratory Study on Marketing Strategies of Selected Home Appliances at Kolkata Metropolitan
}

\author{
CrossMark \\ Chinmoy Ghosh ${ }^{a}$, Sujit Mukherjee ${ }^{b}$
}

Article history: Received 27 December 2018, Accepted: 30 April 2019, Published: 26 June 2019

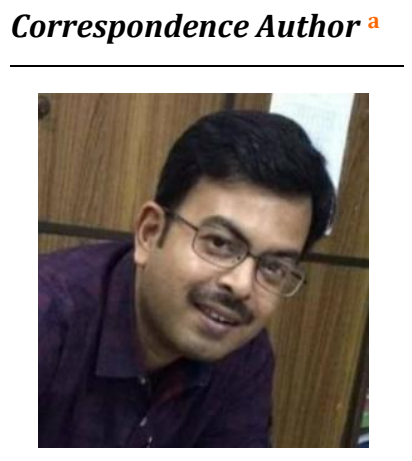

Keywords

customers;

marketing;

poke;

push;

shock-knock;

\begin{abstract}
A study focuses on two aspects first, how existing marketing strategy provides a push the customer for selecting particular home appliances and the second one how demand on customers are motivated though using that marketing strategy. Because marketing strategies are just the ingredients which help to attract the consumer towards the product. So we conclude that our study focuses on two aspects first, how existing marketing strategy proves a push the customer for selecting particular home appliances and the second one how demand on customers are motivated though using that marketing strategy. In both cases, we found that there must be a strong correlation between the marketing strategies which prove a push or poke (shock- knock at the customer's choice) while selecting a particular home appliance.
\end{abstract}

e-ISSN: 2550-7001, p-ISSN: 2550-701X ๑Copyright 2019. The Author. SS Journals Published by Universidad Técnica de Manabí. This is an open-access article under the CC BY-SA 4.0 license (https://creativecommons.org/licenses/by-sa/4.0/) All rights reserved.

\section{Contents}

Abstract

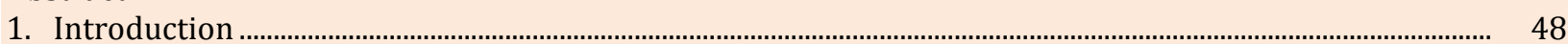

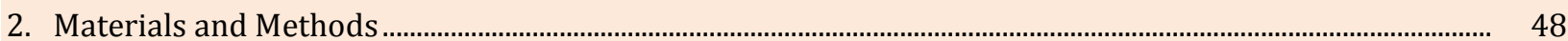

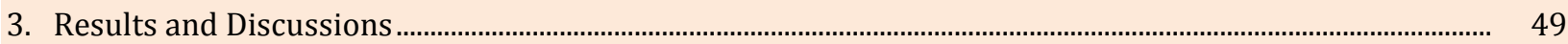

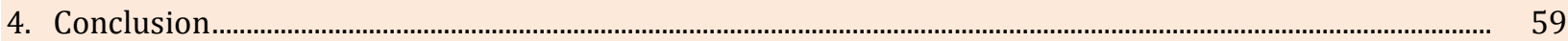

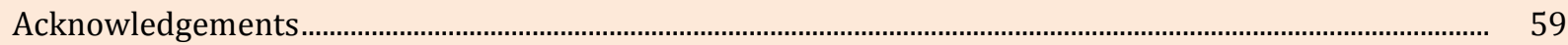

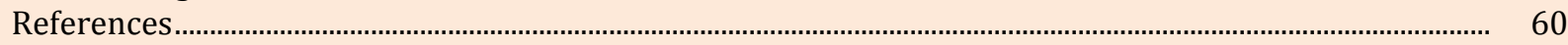

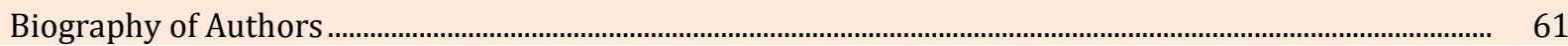

a Mulana Abdul Kalam University of Technology, Kolkata, India

b Mulana Abdul Kalam University of Technology, Kolkata, India 


\section{Introduction}

These marketing strategies are just the ingredients which help to attract the consumer towards the product. Basically marketing strategies of home appliances depends on two parts (Adetunji et al., 2017; Aghara et al., 2018; Basak \& Khanna, 2017).

a. Elements of the marketing mix and customer choice

b. Need an analysis of customer

In that paper, we select 5 home appliances namely T.V., Air-Conditioning machine, Refrigerator, Microwave, washing machine, etc. For analyzing the marketing strategy elements relates to customers choice and subsequently how the demand of customers are motivated (Elitok \& Toksoy, 2003; Ghosh, 2017; Jaminyasa et al., 2017). We select 10 marketing strategies such as Product quality, Extended Warranty, Custom design, Upgraded technology, Discounting, Offer, Value for money, Traditional marketing channels, Social media, Remarketing strategies. Again we select 5 elements which can affect the customers demand such as Esteem to need, Ego needs, Just a push, Budget- Quality-Availability-User friendly, Shape of customer need, etc.

With the help of the above elements, we try to develop a new strategy which is actually related to all marketing strategies. The objective of the study.

a. Correlation between the elements of marketing strategies

b. How Customers demands are motivated

\section{Materials and Methods}

a. Primary data survey

b. Questioner preparation

c. The correlation coefficient of marketing strategies of home appliances

d. Chi-square for hypothesis testing based on marketing strategies of home appliances

We prepare a questionnaire and divide it into two part for our study purpose.

\section{Questionnaire}

1) What do you think the product quality is an important element for purchasing decisions of home appliances?

A. Yes B. No

2) Does extended warranty features provide any effect while selecting home appliances for purchase?

A. Yes B. No

3) Custom design of home appliances attracted you towards the product for taking purchase decision?

A. Yes B. No

4) When you purchase home appliances actually looking for upgraded technological features of the product?

A. Yes B. No

5) Do you think to select a particular home appliance discounting on pricing help you to make purchasing decisions?
A. Yes
B. No

6) Do different offers regarding purchasing of home appliances provide any effect on your selection decision?

A. Yes B. No

7) Do you believe the value for money concept when purchasing decisions of home appliances?

A. Yes B. No

8) Do you think traditional marketing channels help you to locate your particular home appliance?
A. Yes
B. No 
9) Now in the current social media era do you think it channelizes the particulate product to their ultimate customer?
A. Yes
B. No

10) Do you think remarketing strategy re-create new demand for home appliances?
A. Yes
B. No

\section{Results and Discussions}

We select five home appliances namely washing machine, air conditioner, microwave, refrigerator, and television set. Data source - questioner (primary data). Sample size-1000. Data collection zone- Kolkata. Questionnaire type - close-ended. Type of study - exploratory analysis. Tools - Ms excel for graph and charts, Minitab for co-relation analysis. In our study first 10 questions are related with Mac Arthy 4P'S.

Table 1

Price, place, product, promotion

\begin{tabular}{llll}
\hline Product & Place & Price & Promotion \\
\hline $\begin{array}{l}\text { product quality } \\
\text { extended warranty }\end{array}$ & remarketing strategy & $\begin{array}{l}\text { discounting } \\
\text { offers }\end{array}$ & $\begin{array}{l}\text { social media } \\
\text { traditional marketing } \\
\text { channels }\end{array}$ \\
$\begin{array}{l}\text { custom design } \\
\text { upgraded technology }\end{array}$ & & value for money & \\
\hline
\end{tabular}

Now according to our survey report, we analyze one by one the elements

Table 2

A primary information of the first segment of our data collection

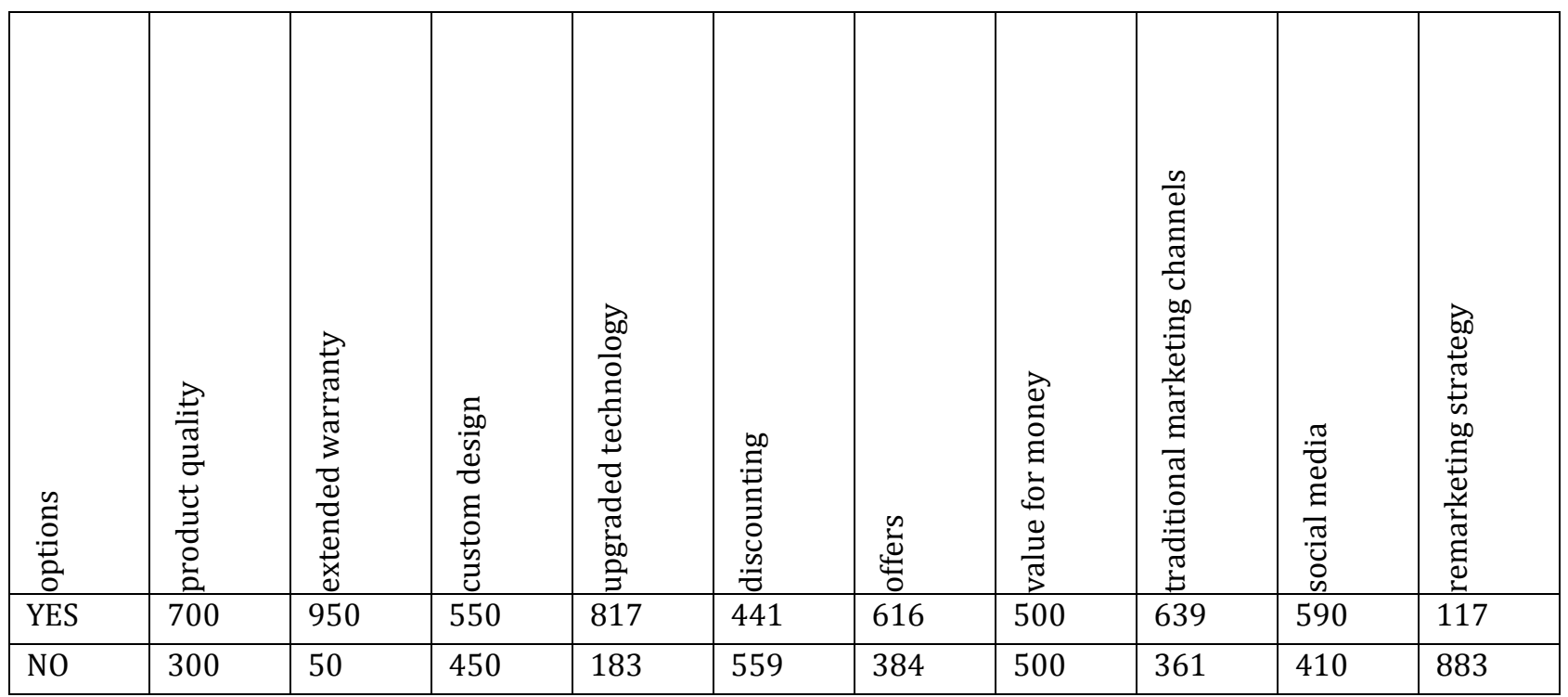

\section{Product quality}

Product quality is not easy to describe, the word Quality since it is seeming differently by the different set of persons. If specialists are asked to define quality, they may give different replies subject on their individual

Ghosh, C., \& Mukherjee, S. (2019). An exploratory study on marketing strategies of selected home appliances at kolkata metropolitan. International Journal of Social Sciences and Humanities, 3(2), 47-61. https://doi.org/10.29332/ijssh.v3n2.292 
partialities. These may be similar to following listed expressions. According to specialists, the word quality can be described either as.

a. Suitability for use or persistence.

b. To do a right item at first spell.

c. To do the right thing at the right time.

d. Find and know, what consumer needs?

e. Structures that meet consumer wants and give customer desire.

f. Freedom from lacks or flaws.

g. Conformance to values.

h. Value or value for money, etc.

Keeping all the certain things we design our first question, most of the respondents ( 700 ) tell us product quality is an important element for purchasing decisions of home appliances.

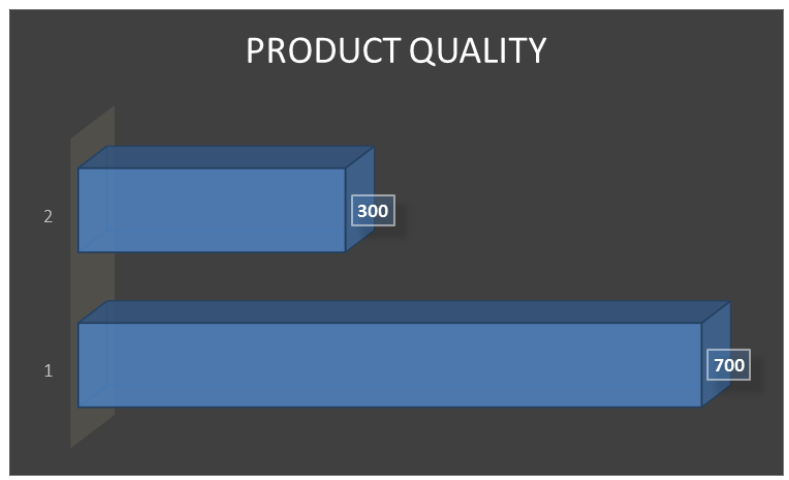

\section{Extended warranty}

An extension of the attention period on a standard warranty (Kotler, 2005; Kotler \& Armstrong, 2006; Mucuk \& Alptekin, 2008). With an extended warranty, the consumer is able to cover the time that the producer is liable to pay for covered incidents. Consumers are frequently given the option to include the extra care either at the time of purchase or when the standard warranty is imminent its end date.

In our study, 95\% respondent said that extended warranty features provide them an extra satisfaction selecting home appliances for purchasing decisions.

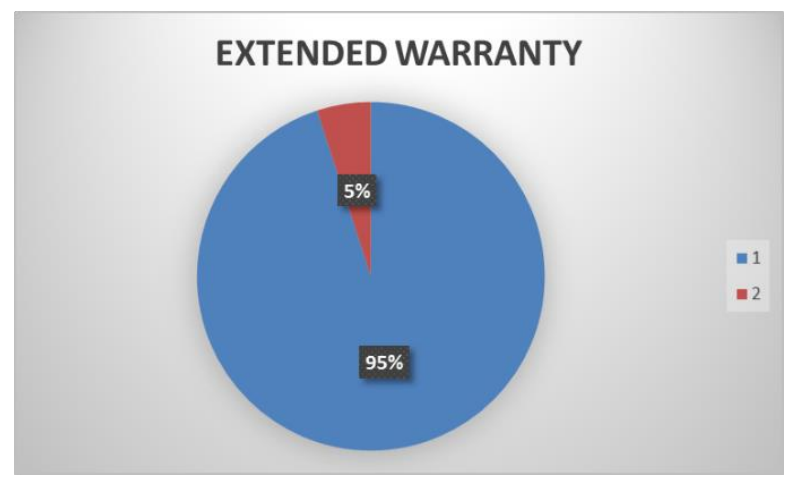

\section{Custom design}

Custom design is a procedure for conniving combined tracks by stipulating the layout of each individual transistor and the interconnections between them. In our study, 550 respondents prove a positive impact on the Custom design of home appliances attracted them towards the product, for taking a purchase decision. 


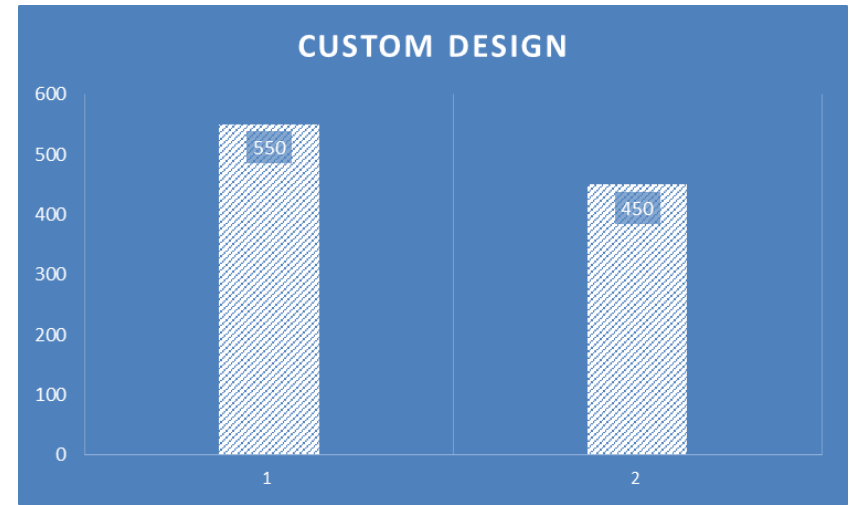

\section{Upgraded technology}

Technology means the systematic application of human knowledge to the practical field of industry. Upgraded technology is just the development of the technical part to make the product more user-friendly (Ogunsiji \& Ladanu, 2017; Udayana, 2017; Uztuğ, 2003). 817 respondents said that When they purchase home appliances, actually looking for upgraded technological features of a particular product.

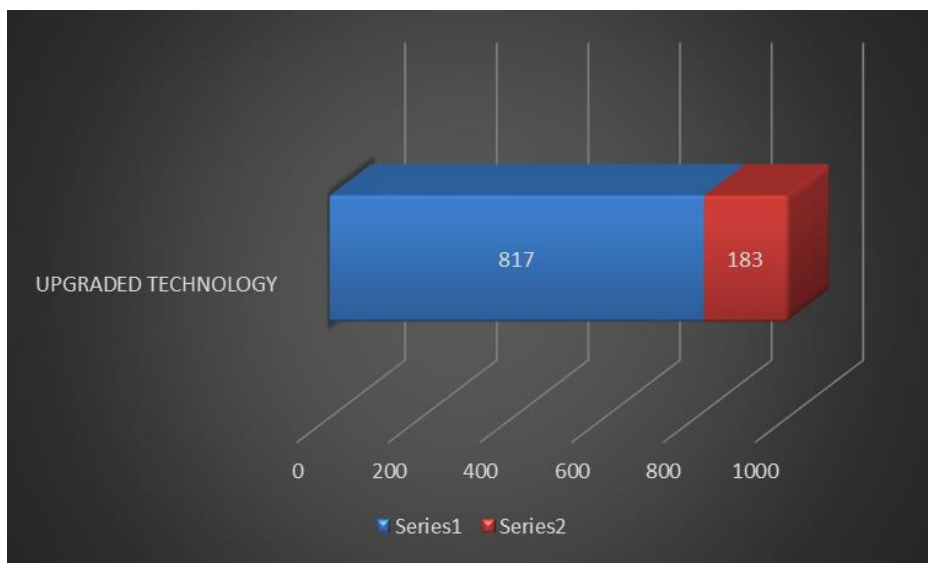

\section{Discounting}

Discounts, loyalty offers and bulk buy pricing is common business practice and relates with-

a. Move stock

b. Appeal new customers

c. Reach sales targets during a slow sales period.

d. Before start cutting sales price in half though - in the hope of drumming up sales - do some planning to make sure still making a profit for the extra orders coming in, that is the motto of discounting techniques.

In our study, $56 \%$ of respondents said that discounts on home appliances help them to make purchasing decisions.

Ghosh, C., \& Mukherjee, S. (2019). An exploratory study on marketing strategies of selected home appliances at kolkata metropolitan. International Journal of Social Sciences and Humanities, 3(2), 47-61. https://doi.org/10.29332/ijssh.v3n2.292 


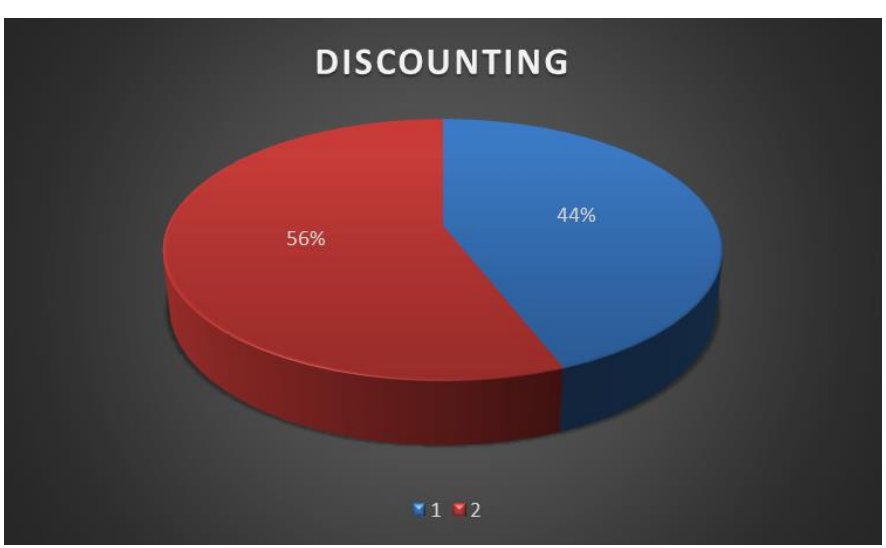

Offer

The Offer is a totally critical part of the Creative Procedure and the most important component in driving response. The Offer has the power to control both response quantity and response quality. The Offer should be one of the first items you consider when planning a direct mail campaign, but too often, it is treated as an afterthought. Too many campaigns suffer as a result. If customers already have an Offer with a track record of results, the company can recommend new offers (or modified offers) intended to improve response quantity or better quality. In our study, 616 respondents said that different types of offers regarding purchasing of home appliances, attract them to consume the particular product.

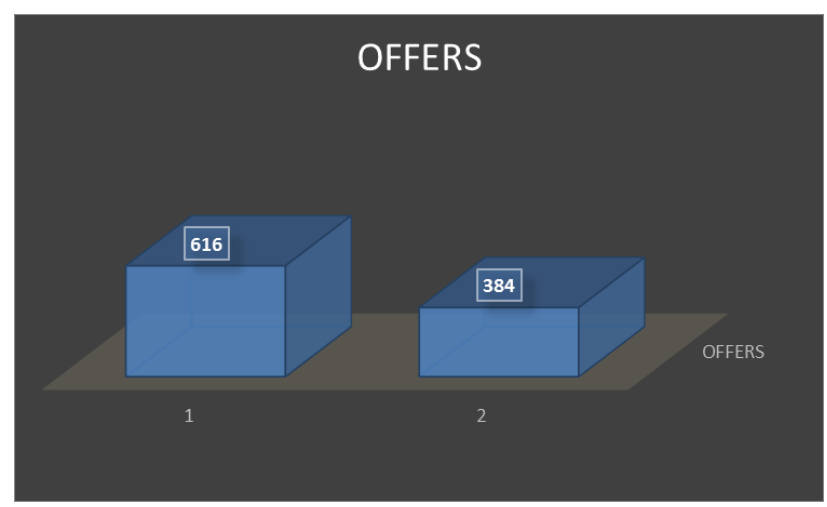

Value for money

A measure of quality that measures the financial cost of the product or service against the quality and/or benefits of that product or service, taking into account individual factors such as fitness for purpose, along with whole-of-life costs such as installation, keep fit, preservation and removal, and depletion. In our study respondents answer denotes a 50:50 situation relating to the matter. Value For Money concept, for selecting home appliances. 


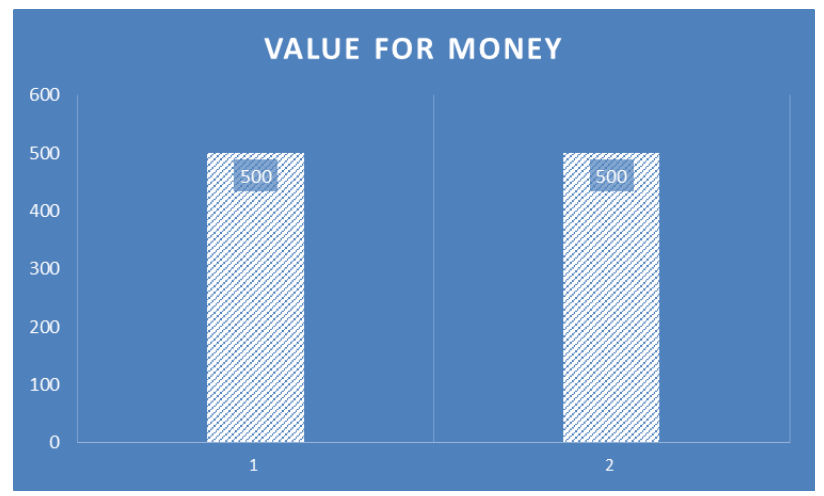

\section{Traditional marketing channels}

Traditional marketing refers to any type of promotion, advertising or campaign that has been in use by concerns for years, and that has a proven success rate. Approaches of traditional marketing can include print advertisements, announcements, brochures or leaflets, TV, newspaper, radio, etc. In our study, 639 respondents said that they did not believe that traditional marketing channels help them to take any decisions for selecting a particular home appliance.

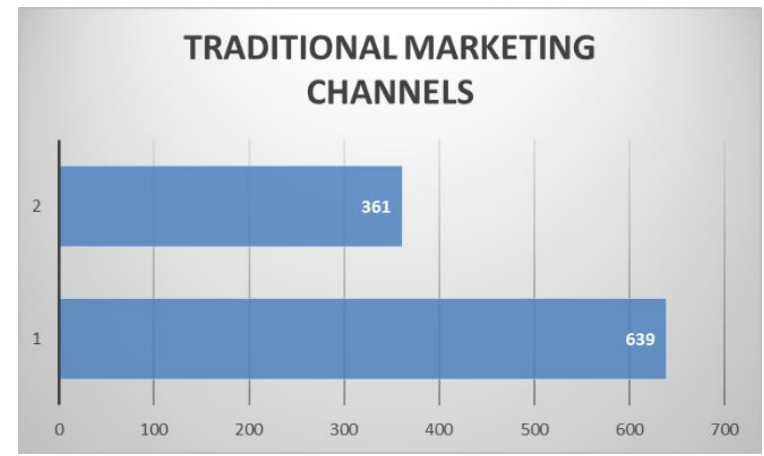

\section{Social media}

The relationship between a brand and consumer has changed melodramatically thanks to the influence of social media. It has given huge control and power to consumers and large companies and well-known brands no longer have the so-called upper hand. Top nick executives and business owners have silent that social media can make or break their business, so they have taken the chance to build an occurrence on social media places like Facebook and Twitter to systematize business. By using social media, businesses now can create plans after they analyze the analytics to appreciate the target consumer's demands and likes/dislikes. But in our study provide that $59 \%$ of respondents do not think that social media don't have strong enough to control the purchasing decisions of an individual for selecting a particular home appliance.

Ghosh, C., \& Mukherjee, S. (2019). An exploratory study on marketing strategies of selected home appliances at kolkata metropolitan. International Journal of Social Sciences and Humanities, 3(2), 47-61. https://doi.org/10.29332/ijssh.v3n2.292 


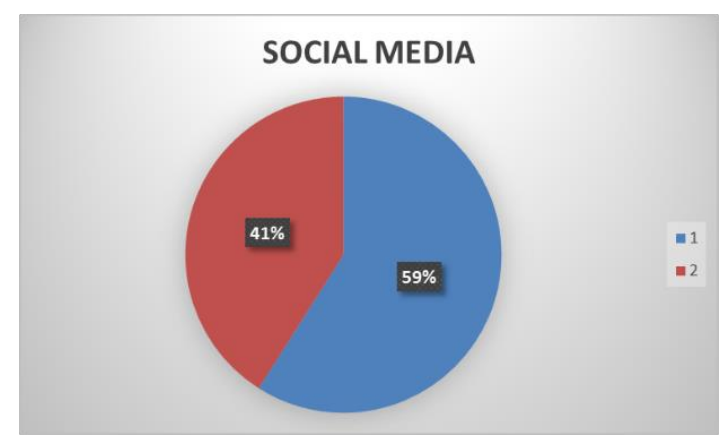

\section{Remarketing strategy}

Remarketing can be a powerful transfiguration tool. Serving ads to users who have before consumed your product keeps you in front of prequalified predictions. But...if not done well it can be an enormous waste of time, money and resources. So, a remarketing strategy requires three elements:

a. An audience

b. Ads - especially copy! - specific to the audience

c. A well-defined goal

In our study, 883 respondents said that remarketing strategy re-create new demand for home appliances.

\section{Correlation coefficient analysis}

Correlations: Product Qual, Extended War, Custom Design, Upgraded Tec, ...

Product Qual Extended War Custom Design Upgraded Tec

\section{Extended war $\quad 1.000$}

Custom desig $\quad \underset{*}{1.000} \quad 1.000$

$\begin{array}{rccc}\text { Upgraded tec } & 1.000 & 1.000 & 1.000 \\ * & * & * & \end{array}$

Discounting $\begin{array}{ccccc}-1.000 & -1.000 & -1.000 & -1.000\end{array}$

$\begin{array}{ccrrrr}\text { Offers } & 1.000 & 1.000 & 1.000 & 1.000\end{array}$

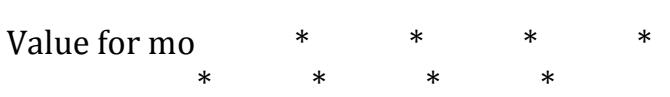

$\begin{array}{crrrr}\text { Traditional } & 1.000 & 1.000 & 1.000 & 1.000 \\ * & * & * & * & \end{array}$

$\begin{array}{ccccc}\text { Social media } & 1.000 & 1.000 & 1.000 & 1.000\end{array}$

$\begin{array}{lcccc}\text { Remarketing } & -1.000 & -1.000 \quad-1.000 & -1.000\end{array}$ 


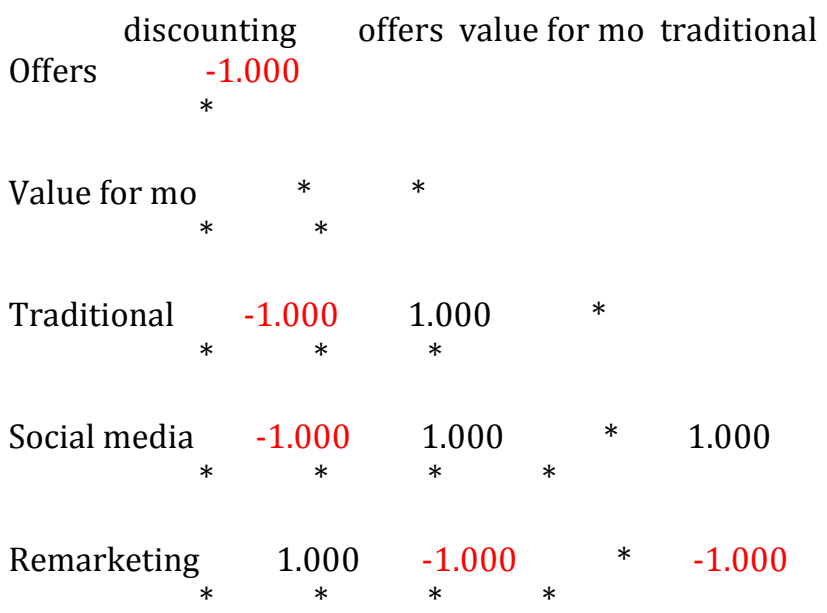

social media

$\operatorname{Remarketing}_{*} \quad-1.000$

Cell Contents: Pearson correlation

P-Value

Now we can find that most of the marketing strategy elements are $(+\mathrm{v}$ e) related and some of them are $(-\mathrm{v}$ e )correlated which are marked red in the above result, but the result proved a strong correlation between marketing strategies.

Chi-square test of marketing strategy elements.

On the basis of the objective of our study we frame our hypothesis for phase1, and try to establish our work by testing the hypothesis.

H0: No relationship exists on the categorical variables of home appliances marketing strategies

H1: There is a definite relationship between the categorical variables of home appliances marketing strategies

\section{Chi-Square Test: Product Qual, Extended War, Custom Design, Upgraded Tech, Discount}

Expected counts are printed below observed counts. Chi-Square contributions are printed below expected counts

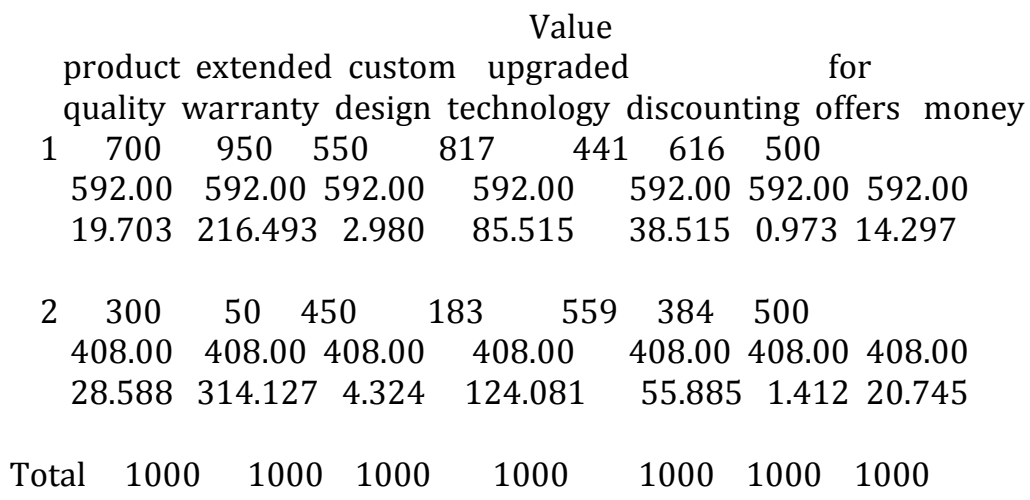

Ghosh, C., \& Mukherjee, S. (2019). An exploratory study on marketing strategies of selected home appliances at kolkata metropolitan. International Journal of Social Sciences and Humanities, 3(2), 47-61. https://doi.org/10.29332/ijssh.v3n2.292 


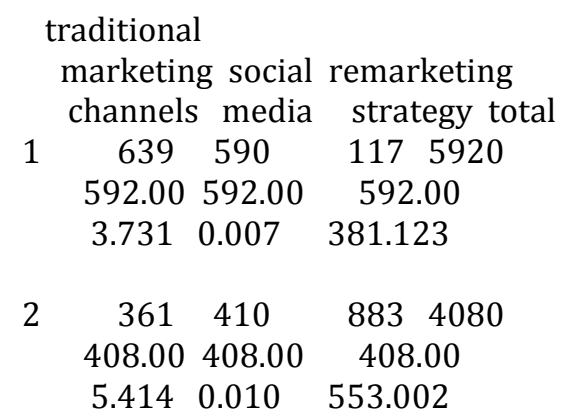

In our study, we find that p-value .000 . So we reject the null hypothesis because the significance is .000, which is substantially less than .05. So, we can say that there is statistical evidence that the categorical variables (Home appliances marketing strategies) influenced customers buying decisions.

$2^{\text {nd }}$ part of our paper relates to demand analysis of customers.

In our study, we focus on two needs of customers ego need and esteem need, on that basis we design the $2^{\text {nd }}$ phase of our questionnaire as follows. As an individual customer, what do you think?

I. marketing strategy of home appliances offering by different companies are just trying to shape customer needs ------
A. agree
B. disagree

II. purchasing a particular brand of home appliances, fulfill you esteem need--------

A. agree B. disagree

III. purchasing decisions of home appliances are just a choice of the fulfilment of ego need-------

A. agree B. disagree

IV. is looking for when selecting a home appliance combination of budget, quality, availability, user-friendly features-------
A. agree B. disagree

V. marketing strategy is just a push from the companies for fulfilling their ultimate goal-------
A. agree
B. disagree

\begin{tabular}{|c|c|c|c|c|c|}
\hline Options & $\begin{array}{l}\text { The shape of } \\
\text { customer need }\end{array}$ & $\begin{array}{l}\text { Esteem } \\
\text { need }\end{array}$ & Ego & Just a push & $\begin{array}{l}\text { Budget, Quality, Availability, } \\
\text { User-friendly }\end{array}$ \\
\hline Agree & 549 & 681 & 538 & 600 & 771 \\
\hline Dis- & 451 & 319 & 462 & 400 & 229 \\
\hline
\end{tabular}




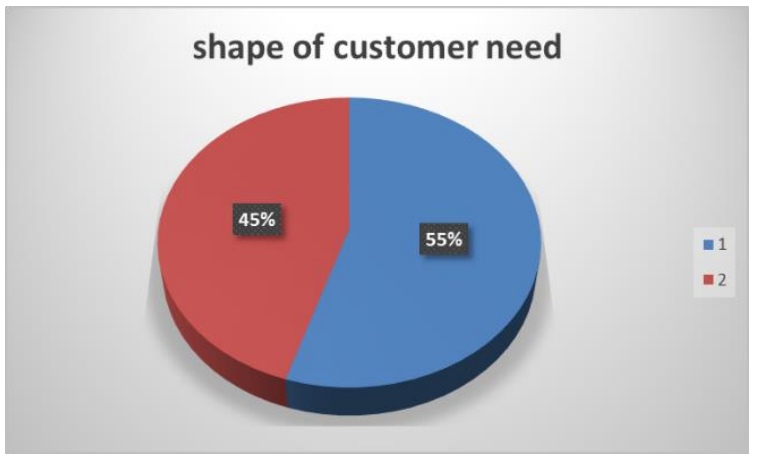

$55 \%$ of respondents believed that the marketing strategy of home appliances are nothing but an effort to shape customer needs by home appliances companies.

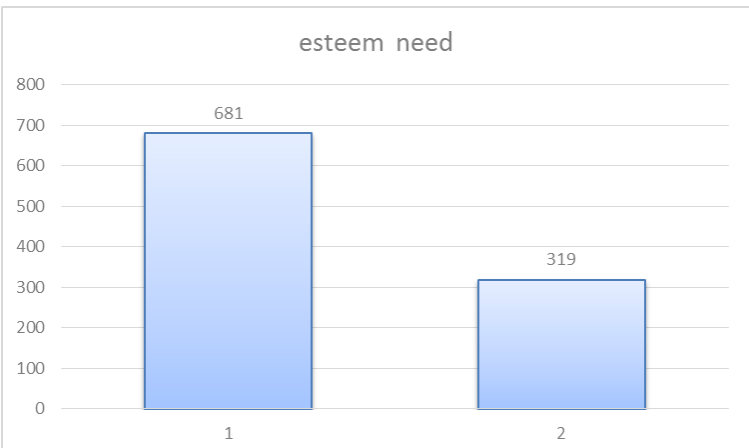

Most of (681) the customers believed that purchasing a particular brand of home appliances, to fulfill their esteem need.

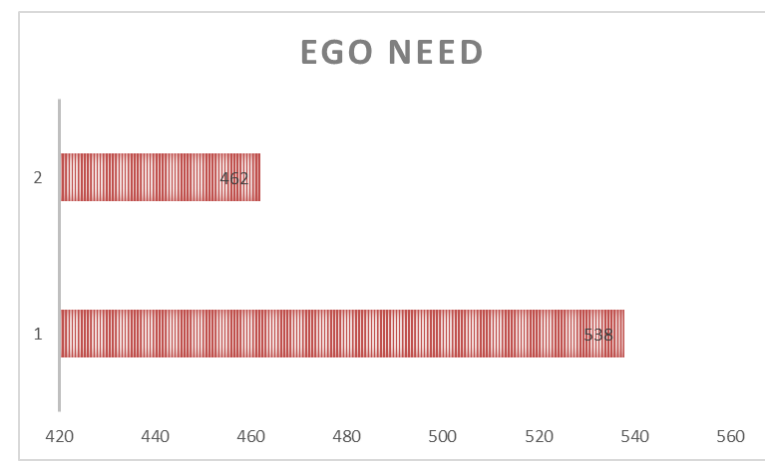

538 customers of our study said that purchasing decisions of home appliances are nothing but fulfillment of ego need.

Ghosh, C., \& Mukherjee, S. (2019). An exploratory study on marketing strategies of selected home appliances at kolkata metropolitan. International Journal of Social Sciences and Humanities, 3(2), 47-61. https://doi.org/10.29332/ijssh.v3n2.292 


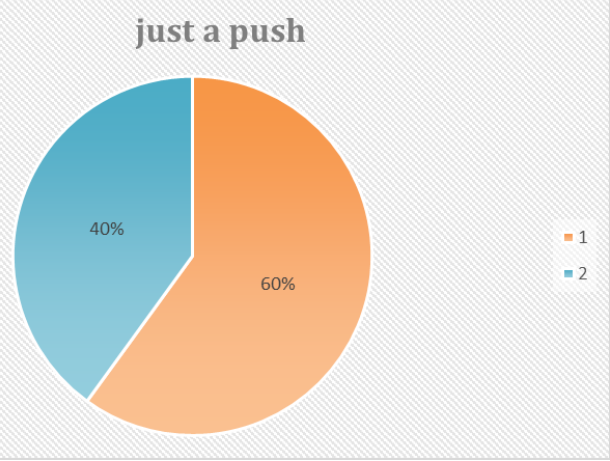

$60 \%$ of respondents believed that marketing strategies of home appliances of different companies are just a push to their target customers to achieving their goal.

\section{BUDGET, QUALITY, AVAILABLITY, USER \\ FRIENDLY}
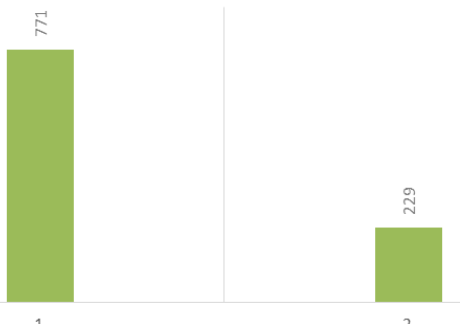

771 respondents said that when they select a particular home appliance actually looking for budget capability, quality of the product, and user-friendly characteristic of the product.

Now correlation analysis of $2^{\text {nd }}$ part

Correlations: the shape of cus, esteem need, ego need, just a push, budget, quality

shape of cus esteem need ego need just a push

esteem need $\quad 1.000$

*

ego need $\quad 1.000 \quad 1.000$

$\begin{array}{lll}* & * \\ \text { just a push } & 1.000 \quad 1.000 & 1.000\end{array}$

$\begin{array}{lllll}* & * & * & & \\ \text { budget,quali } & 1.000 & 1.000 & 1.000 & 1.000\end{array}$

Cell Contents: Pearson correlation

P-Value

So we can find that focusing on the demand of customers the factors of motivating demand relate with each other. For phase two our hypotheses are.

H0: No relationship exists on the categorical variables relating to the demand of customer for selecting particular home appliances

H1: There is a definite relationship between the categorical variables relating to demand of customer for selecting particular home appliances 
Chi-square test: product qual, extended war, custom desig, upgraded tec, discou

Expected counts are printed below observed counts. Chi-Square contributions are printed below expected counts

Value product extended custom upgraded for quality warranty design technology discounting offers money

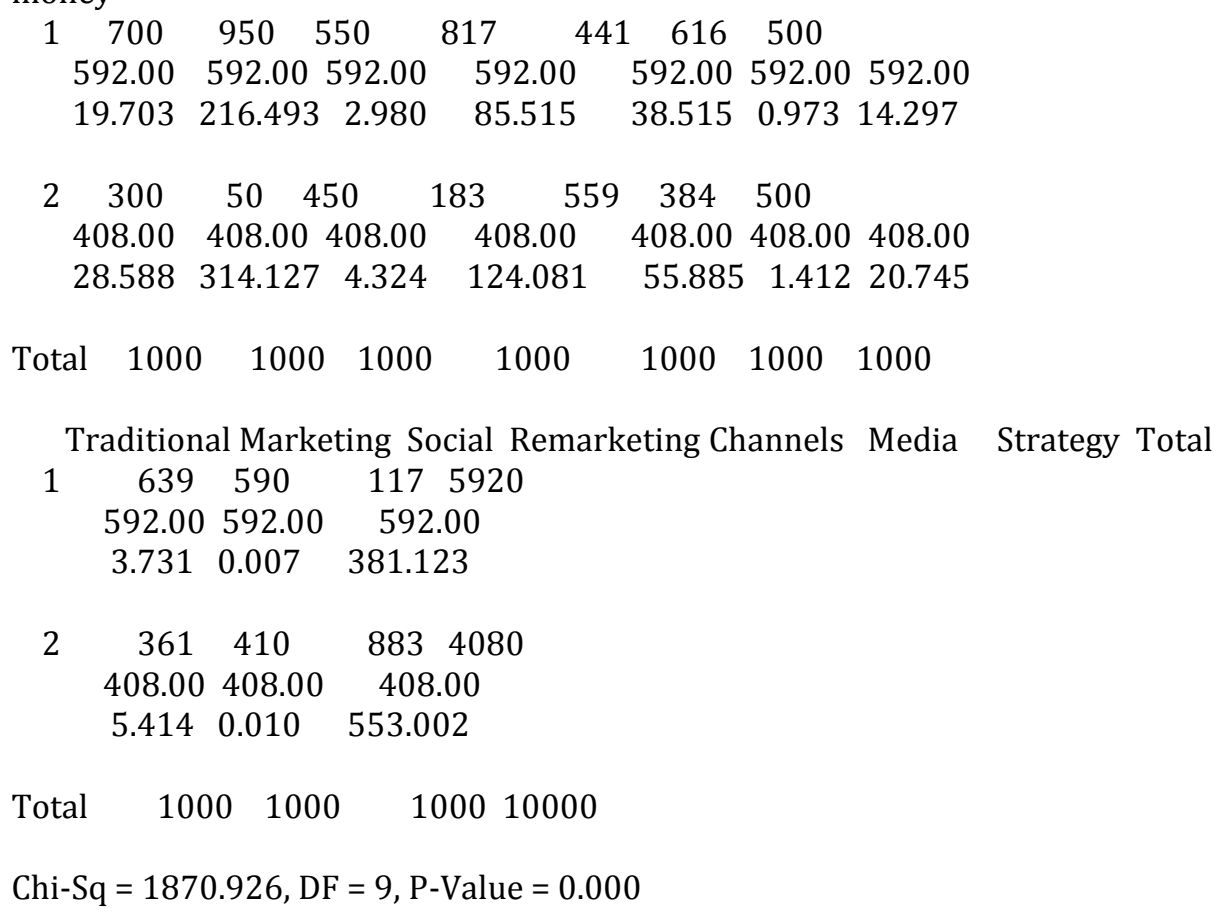

In our study, we find that p-value .000 . So we reject the null hypothesis because the significance is .000, which is substantially less than .05. So, we can say that there is statistical evidence that the categorical variables (Demand of customer for selecting particular Home appliances) influenced customers buying decisions.

\section{Conclusion}

So we conclude that our study focuses on two aspects first, how existing marketing strategy proves a push the customer for selecting particular home appliances and the second one how demand on customers are motivated though using that marketing strategy. In both cases, we found that there must be a strong correlation between the marketing strategies which prove a push or poke (shock- knock at the customer's choice) while selecting a particular home appliance.

\section{Acknowledgments}

The authors would like to thank the editorial team of IJSSH for their valuable time, support, and advice in completing the current research.

Ghosh, C., \& Mukherjee, S. (2019). An exploratory study on marketing strategies of selected home appliances at kolkata metropolitan. International Journal of Social Sciences and Humanities, 3(2), 47-61. https://doi.org/10.29332/ijssh.v3n2.292 


\section{References}

Adetunji, A., Adetunji, A., Adeleke, E., \& Madubuike, S. (2017). Deregulation: the effect of market-led approach to Nigerian universities management. International Journal of Social Sciences and Humanities, 1(1), 1-8. https://doi.org/10.29332/ijssh.v1n1.6

Aghara, V. N., Nwaizugbo, I. C., Oparah, P. C., \& Ifeanyichukwu, C. D. (2018). Sales promotion as a leverage strategy for improving sales and profitability in alcohol beverage industry. International research journal of management, IT and social sciences, 5(4), 18-25.

Basak, A., \& Khanna, K. (2017). A study on the selection criteria of different hotels of Delhi NCR in accordance to the hr policies and market trends. International Journal of Social Sciences and Humanities, 1(1), 27-38. https://doi.org/10.29332/ijssh.v1n1.13

Elitok, B., \& Toksoy, S. (2003). Hadi markalaşalım: Marka liderliği. Sistem yayıncılık.

Ghosh, C. (2017). A study on - evaluating marketing strategies adopted by home appliance for economic development in India. International Journal of Social Sciences and Humanities, 1(1), 9-15. https://doi.org/10.29332/ijssh.v1n1.7

Jaminyasa, I. M., Pulawan, I. M., Martadiani, A. M., \& Amerta, I. M. S. (2017). The marketing mix affect on the consumer buying decision (case study of sausage products at PT. Aroma Denpasar). International Journal of Social Sciences and Humanities, 1(2), 65-74. https://doi.org/10.29332/ijssh.v1n2.44

Kotler, P. (2005). A'dan Z'ye Pazarlama, Mediacat Yayınları, 2. Baskı Đstanbul.

Kotler, P., \& Armstrong, G. (2006). Principles of marketing management. New Delhi: Hall of India private limited.

Mucuk, M., \& Alptekin, V. (2008). Türkiye'de Vergi ve Ekonomik Büyüme İlișkisi: VAR Analizi (19752006). Maliye Dergisi, 155, 159-174.

Ogunsiji, A., \& Ladanu, W. (2017). A theoretical study of performance measures in the strategic and corporate entrepreneurships of firms. International Journal of Physical Sciences and Engineering, 1(1), 72-80. https://doi.org/10.21744/ijpse.v1i1.15

Udayana, I. G. B. (2017). Marketing strategies arabica coffee with information technology in Kintamani District Bangli. International research journal of engineering, IT \& scientific research, 3(3), 93-102.

Uztuğ, F. (2003). Markan Kadar Konuş, Mediacat Kitapları, 2. Baskı, İstanbul. 


\section{Biography of Authors}

\begin{tabular}{||l|l||}
\hline & $\begin{array}{l}\text { Chinmoy Ghosh, Research scholar MAKAUT in Management, West Bengal, India. } \\
\text { Email: chin.lord@gmail.com }\end{array}$ \\
\hline
\end{tabular}

Ghosh, C., \& Mukherjee, S. (2019). An exploratory study on marketing strategies of selected home appliances at kolkata metropolitan. International Journal of Social Sciences and Humanities, 3(2), 47-61. https://doi.org/10.29332/ijssh.v3n2.292 